\begin{tabular}{|c|c|}
\hline Title & $\begin{array}{l}\text { V arious scarification treatments produce different regeneration potentials for trees and forbs through changing soil } \\
\text { properties }\end{array}$ \\
\hline Author(s) & Y amazaki, Haruka; Y oshida, Toshiya \\
\hline Citation & $\begin{array}{l}\text { Journal of Forest Research, 25(1), 41-50 } \\
\text { https://doi.org/10.1080/13416979.2019.1706798 }\end{array}$ \\
\hline Issue Date & $2020-01-03$ \\
\hline Doc URL & http:/hdl.handle.net/2115/80091 \\
\hline Rights & $\begin{array}{l}\text { This is an A ccepted Manuscript of an article published by Taylor \& Francis in Journal of Forest Research on } 03 \text { January } \\
\text { 2020, available online: http://www.tandfonline.com/https://doi.org/10.1080/13416979.2019.1706798. }\end{array}$ \\
\hline Type & article (author version) \\
\hline File Information & A rticle.pdf \\
\hline
\end{tabular}

Instructions for use 
1 Various scarification treatments produce the different regeneration

2 potentials for trees and forbs through changing soil properties

3 Haruka Yamazaki ${ }^{\text {a* }}$ and Toshiya Yoshida ${ }^{\text {a }}$

$4{ }^{a}$ Field Science Center for Northern Biosphere, Hokkaido University; 250 Tokuda,

5 Nayoro, 096-0071, Hokkaido, Japan

6 * Corresponding author: halyamazaki@fsc.hokudai.ac.jp

7 


\section{Various scarification treatments produce the different regeneration 9 potentials for trees and forbs through changing soil properties}

Soil scarification removed surface layers including nutrients and buried seeds. The purpose of this study was to evaluate the success of alternative practices which intentionally leave the surface soil (screening and replacing) along with the standard scarification. We focused on soil properties, the density of buried seeds, the invasion of competitive vegetation, and the regeneration of tree species. There were significant differences in soil properties among the treatments. Soils that were treated with the replacing treatment had the highest water contents from the surface layer to the deep layer in the lower slope in particular. On the other hand, there were higher densities of tall forb germinated from rhizomes, which are likely to shade tree species, with the replacing particularly in the lower slope locations. The residual buried seed densities in the soil were estimated to be significantly higher in the screening than the replacing. Phellodendron amurense, producing seed bank and having dry tolerance, exhibited the greatest seedling density with the screening. However, there was no significant difference between screening and replacing in Betula species which has higher water demands. In conclusion, it is important that screening and replacing should be used properly according to the site condition and target tree species. The replacement had the advantage of retaining higher water content, but it is suggested that the screening is a better option when intended for regeneration from buried seeds and when many tall forb species grow alongside dwarf bamboo prior to treatment.

Keywords: Surface soil disturbance; selection of silvicultural practice; buried seeds; tall forb species; assisted natural regeneration

\section{Introduction}

An increased expectation for ecosystem services has raised awareness of the importance of nature conservation even in primary industries (Butchart et al. 2010; Benayas and Bullock 2012). However, sustainable management with due consideration of conservation generally remains underdeveloped in forestry (Siry et al. 2005), resulting in an increasing global emphasis on the close-to-nature concept, which aims to 
harmonize timber production with ecosystem resilience (Kohm and Franklin 1997;

Messier et al. 2013).

Close-to-nature forest management generally promotes natural regeneration as a method for establishing new forests. It has been reported that planted forests with simple structures for economic efficiency have greatly modified natural patterns and processes, resulting in decreased ecosystem resilience (Thompson et al. 2009). By contrast, natural regeneration allows forest establishment from naturally dispersed seeds or vegetative propagation (e.g., sprouting), resulting in more natural forests that contain tree species and genetic traits that are better suited to local conditions (Schütz 1999; Finkeldey and Ziehe 2004). Furthermore, natural regeneration has various economic advantages compared with planted forests, as tree species that are difficult to grow by planting (e.g., many broadleaf species) can be produced and management costs can be reduced by eliminating the need for planting operations (Shono et al. 2007; Gonza'lezRodri'gues et al. 2011). However, there is a major disadvantage in natural regeneration, i.e., its reliance on natural seed dispersal; its success varies depending on the level of seed production and the suitability of the understory conditions (Löf et al. 2012;

54 Fløistad et al. 2018). Therefore, assistance practices are often employed to improve the site conditions for seed germination and seedling establishment (Löf et al. 2012; Nyland 2016).

Such assistance practices that are employed vary greatly depending on the local conditions at a particular site (Löf et al. 2012). In Hokkaido, north Japan, dwarf bamboos can vegetatively reproduce from the root system, causing regeneration failure among target tree species (Narukawa and Yamamoto 2002; Noguchi and Yoshida 2004;

61 Yoshida et al. 2005); therefore, removal of entire bamboo plants using heavy machinery

62 (known as scarification) has been widely performed since the 1960s (Umeki 2003). 
63 Scarification is considered to have a relatively high success rate, producing secondary

64 forests of Betula species, which are typical native pioneer trees (Umeki 2003; Prévost et

65

66

67

68

69

70

al. 2010). Consequently, the increased commercial demand for the timber of Betula species in recent years (Ito et al. 2018) has resulted in the use of this method as a candidate alternative to conifer planting in this region, which is consistent with the close-to-nature concept.

When carrying out scarification, an appropriate method should be used that considers both the site conditions and species characteristics. Indeed, scarification has occasionally been shown to have a negative effect on the target species, with regeneration failing in some instances, likely due to the vigorous growth of competitive vegetation, such as tall forb species (Zaczek 2002; Yoshida et al. 2005; Fløistad et al. 2018). Therefore, a quantitative evaluation of the influence of scarification on not only the target tree species but also competitive vegetation is required.

In this study, we paid special attention to the practices leaving surface soil in the scarification treatment. In standard soil scarification, the surface soil layers where the root systems of dwarf bamboos are concentrated are largely removed. However, this also results in large amounts of nutrients (Aoyama et al. 2009; Yildiz et al. 2009) and any buried seeds (Osumi and Sakurai 1997; Reyes et al. 2014) being lost from the site. Consequently, in recent years, alternative practices have been proposed that intentionally leave the surface soil at the site. These techniques have been reported to increase the growth of regenerated target trees (Aoyama et al. 2009) as well as the number of emerged seedlings from buried seeds (Sato 1998; Goto and Tsuda 2007). However, no studies to date have considered the detailed procedure for leaving the surface soil or the possible effects on competitive vegetation. 

known as "screening" and "replacing" (see the Materials and methods section for details), and unexpectedly found that the number of seedlings that germinated from buried seeds varied significantly between these, possibly indicating that both the amount and quality of the soil that is left is important (Yamazaki and Yoshida 2018).

Therefore, the purpose of the present study was to evaluate the success of these scarification practices along with the standard method in terms of soil properties, the density of buried seeds, the invasion of competitive vegetation, and the regeneration of tree species. In terms of soil properties, the moisture condition is particularly important in determining the initial establishment of seedlings just after germination (Madsen 1995; Resco de Dios et al. 2005). Therefore, we focused on the surface soil water content and related soil characteristics (McNabb et al. 2001; Ares et al. 2005; SiegelIssem et al. 2005). We used the results to evaluate the suitability of each practice for increasing the success of regeneration depending on the target tree species and site conditions.

\section{Materials and Methods}

\section{Study site and treatments}

104 This study was carried out in the Uryu Experimental Forest of Hokkaido University in

105 Hokkaido, northern Japan. Mean annual temperature and precipitation are respectively

$1063^{\circ} \mathrm{C}$ and $1400 \mathrm{~mm}$, with the maximum snow depth over $200 \mathrm{~cm}$. The forest is largely

107 dominated by a mixed conifer-broadleaf stand consisting mainly of Abies sachalinensis

108 (Fr. Scham.) Masters, Querucus crispula Blume., B. ermanii Cham. and B. platyphylla

109 var. japonica (Miq.) Hara (the nomenclature was followed by Yonekura and Kajita 110 2003). 
The study site was established in large canopy openings created by past logging

112 and wind-fall disturbances on gentle slopes (slope inclinations $10-12^{\circ}$ ) in 0.5 ha of a

113 natural stand. The understory was mainly covered with dense dwarf bamboo, Sasa

114 senanensis (Franch. et Sav.) Rehder. The soil type is brown forest soil that is most

115 common target for scarification treatment. Three experimental areas were located in the

116 center of the canopy openings. Two study-plots, each with an area of $48 \mathrm{~m}^{2}(4 \times 12 \mathrm{~m})$,

117 were established in the upper and lower parts of the slop. Each set of the plots was

118 located within the horizontal distance of approximately $20 \mathrm{~m}$ (differences in elevation

119 were approximately $3.5 \mathrm{~m}$ ). There is a forestry road at the top of the upper study-plots,

120 and we established the ditch to limit a direct inflow from the road.

121 In each of these study plots, we set three subplots (4m square), and three

122 different practices of soil scarification were assigned to each.

123 (1) Scarification: It is a standard treatment in which a power shovel (HITACHI,

124 ZX27U-3) was used to remove understory vegetation with surface soil (up to 5-

$125 \mathrm{~cm}$ depth). The resulting debris was piled outside the area.

126 (2) Screening: The understory vegetation was removed by clamping the bucket of

127 the power shovel, in which the entire plant including the root system is removed.

128 As much soil as possible is shaken off the root debris so as to retain the soil at 129 the site.

130 (3) Replacing: The surface soil with understory vegetation was removed from the

131 site using a power shovel, similar to the standard scarification process. However,

132 the soil was subsequently replaced using a power shovel after a certain period;

133 the duration of 4 weeks was selected in this case to prevent recolonization of

134 dwarf bamboos from root stocks (Aoyama et al. 2009). 
135 The treatments were conducted in the subplots (with c.a. $1 \mathrm{~m}^{2}$ marginal area added)

136 during the summer of 2015.

\section{Soil properties survey}

138 We investigated soil properties of each sub-plot in 2016 and 2017 (1-2 years later after

139 the treatment). In summer, 2016, soil hardness was measured with a tester (Fujiwara

140 Scientific Co. Ltd., Yamanaka's Soil Hardness tester) at three depths $(0-5 \mathrm{~cm}, 5-10 \mathrm{~cm}$

141 and $10-20 \mathrm{~cm}$ ) on the soil profile installed in the marginal area of the sub-plot, and the

142 average of nine repetitive measurements of each sub-plot was used as a representative

143 value. Also, in summer 2017, we brought back soil samples from three soil depths (0-

$1442.5 \mathrm{~cm}, 2.5-5 \mathrm{~cm}$ and $5-10 \mathrm{~cm})$ of $25 \mathrm{~cm}$ square in the sub-plot to the laboratory. Plant-

145 debris (many were dead but some were alive) were derived from the soil using the sieve

146 (4-mm mesh) and washed, and their dry weights $\left(75^{\circ} \mathrm{C}, 48 \mathrm{~h}\right)$ were used as

147 representative measures of plant-debris density. Soil surface temperature was measured

148 with the data logger (Onset Computer Corporation, UA-002-08), at one depth (1-2 cm

149 depth) in the sub-plot. We used the data of 12:00 p.m. in 7 days period (after around no

150 precipitation after 7 days) in summer, 2017, when the soil was considered to be the

151 driest.

152 Soil samples were also collected systematically in the sub-plot at four depths (0-

$1532.5 \mathrm{~cm}, 2.5-5 \mathrm{~cm}, 5-10 \mathrm{~cm}$ and $10-20 \mathrm{~cm}$; one repetition for each sub-plot) using on

154 semicircle-auger (Daiki Rika Kogyo Co. Ltd., $5 \mathrm{~cm}$ in diameter) for measuring soil

155 water content. The sampling was carried out also after no precipitation around 7 days

156 during the summer, 2016. Although it was momentary data, we think that it is sufficient

157 for discussing differences in regeneration among the treatment, because the period is

158 considered to be most severe for living environment for seedlings. We carefully 
removed plant-debris and stones using the sieve (2-mm mesh), and weighted the

160 sample before and after drying $\left(105^{\circ} \mathrm{C}, 24 \mathrm{~h}\right)$ to determine water contents.

At last, we evaluate fine scale soil surface micro-topography in 2017. We took

16270 pictures of the square quadrats, using a digital camera (Nikon Co. Ltd., Coolpix-A).

163 Before taking pictures, we carefully removed all the vegetation and litter to keep the

164 intact surface geometry. 3D-models of the surface were constructed from the pictures

165 using the SfM (Structure from Motion) technology (Agisoft LLC, Photo-Scan). We took

166 ground surface levels resolution with a $2 \mathrm{~cm}$ a square (1600 points quadrat $\left.{ }^{-1}\right)$ on GIS

167 (Esri, Inc., Arc-GIS ver.10.4), and their variance value in each sub-plot was used as an

168 index of soil surface roughness.

\section{Buried seed density}

170 The three practices were conducted at another adjacent location (4m square with three

171 replications) to evaluate the effect on buried seed density. We used industrial glass

172 beads of $2 \mathrm{~mm}$ in diameter (hereafter pseudo-buried seeds), which was equivalent to the

173 seed size of Betula species, for this experiment. Before conducting the practices, we

174 dispersed the pseudo-buried seeds in two ways; for the surface layer, we sowed 70

175 beads $/ \mathrm{m}^{2}$ evenly by hand. On the other hand, we buried at the intersection of every 50

$176 \mathrm{~cm}$ so that there are 70 beads $/ \mathrm{m}^{2}$ respectively for the depths $5 \mathrm{~cm}$ and $10 \mathrm{~cm}$. (totally

177210 beads $/ \mathrm{m}^{2}$ ). Then, after the practices, we extracted all soil to depth $10 \mathrm{~cm}$ in the

$17825 \mathrm{~cm}$ square frame with 4 replications for each treatment. The glass beads in the

179 samples were counted, and were used as an index of residual density of buried seeds in

180 each treatment. We note that, in general, most of buried seeds of tree species are existed

181 in the surface layer (buried seeds of Betula species were present at a depth of $5 \mathrm{~cm}$ or

182 less; Osumi and Sakurai 1997), and their germination rates decrease greatly when the

183 depth exceeds $10 \mathrm{~cm}$ (Benvenuti et al. 2001). 
185 We collected all the germinated seedlings and juveniles in each sub-plot regularly

186 (approximately two-weeks interval) during the whole growing season (June - August)

187 in 2016. We note that the effect of human interventions was negligible, as the sampling

188 was finished before conducting the series of soil collections. Seedlings and juveniles

189 were identified by species and their germination origins (from seed or from rhizome).

190 We noted that it was difficult to identify species of many seedlings among the two

191 Betula species immediately after the germination. Therefore, we treated seedlings of

192 these two species as Betula spp. in this study.

\section{Analysis}

194 The statistical differences among treatments was tested using a generalized liner mixed

195 model (GLMM) in which the three study areas (i.e. canopy openings) was considered as

196 a random effect. The treatments, slope location, and their interaction were used as

197 predictor variables. We assumed a Gaussian distribution with an identity-link function

198 for soil properties and assumed a Poisson distribution with a log-link function for the

199 densities of seedlings or juveniles of the main seven plant species ( 2 tree species and 5

200 competitive species). We selected a final model using AIC value, and carried out the

201 multiple comparisons by Tukey's test. The statistical differences in buried seed density

202 among treatments were tested using a generalized liner model (GLM) and the

203 subsequent by Tukey's test. R 3.1.2 was used (R Development Core Team 2019) for

204 the analyses. 


\section{Results}

\section{Soil properties}

207 There were no significant effects of slope locations on ground surface level, soil

208 hardness, plant-debris density and soil surface temperature (Appendix-table 1). The

209 average of soil surface roughness (variance in height) was significantly high in the

210 replacing (Fig. 1a, $\mathrm{p}<0.01$ ), with no significant difference between the screening and the

211 standard scarification (Fig. 1a, $\mathrm{p}>0.05$ ). Soil hardness was significantly lower in the

212 replacing at the all depths (Fig. $1 \mathrm{~b}, \mathrm{p}<0.001$ ), while there was no significant difference

213 between the screening and the standard scarification (Fig. 1b, p>0.05). Similarly, plant-

214 debris density was significantly more abundant in the replacing (Fig. 1c, p<0.001), with

215 no significant difference between the screening and the standard scarification (Fig. 1c,

$216 \mathrm{p}>0.05$ ). Soil surface temperature was significantly lower in the replacing than in the

217 screening (Fig. 1c, p<0.05), and it was tendency lower in the replacing than in the

218 standard scarification.

219 Soil water contents were significantly high in the lower slope-location in the

220 shallower two depths $(0-2.5 \mathrm{~cm}, 2.5-5 \mathrm{~cm})$ in the standard scarification (Fig. $2 \mathrm{ab}, \mathrm{p}<0.05)$,

221 and three depths $(0-2.5 \mathrm{~cm}, 2.5-5 \mathrm{~cm}, 5-10 \mathrm{~cm})$ in the replacing (Fig. 2 acd, $\mathrm{p}<0.05)$. In

222 contrast, in the screening, the difference was significant only at the depth $2.5-5 \mathrm{~cm}$ (Fig.

$2232 \mathrm{~b}, \mathrm{p}<0.05)$. In the upper slope the differences among the treatments were not found,

224 except for 5-10cm depth (Fig. 2abd, p >0.05). On the other hand, in the lower slope, soil

225 water contents were significantly high in the two treatments leaving surface soil than the

226 standard scarification (Fig. 2, p $<0.01$ ), and they were significantly high in the replacing

227 than the screening in many depths (Fig. 2acd, p<0.05). 
229 The residual pseudo-buried seeds densities in the soil greatly varied among the

230 treatments (Fig. 3a, Appendix-table 2). In the standard scarification, the density was

231 extremely low, showing less than $5 \%(p<0.001)$. Between the two treatments leaving

232 surface soil, the density was significantly higher in the screening $(>50 \%)$ than the

233 replacing (around 35\%; $<<0.05$ ).

\section{Vegetation}

235 The numbers of the seedlings of Betula spp. and Phellodendron amurense, which were

236 main tree species, were not influenced by the slope-location (Appendix-table 2, $\mathrm{p}>0.05$ ),

237 while they were significantly less abundant (less than a quarter) in the standard

238 scarification (Fig. 3, p<0.001). Between the two treatments leaving surface soil, there

239 was no significant difference in Betula spp. (Fig. 3b, p>0.05), but they were

240 significantly more abundant in the screening than the replacing in P. amurense (Fig. 3c,

$241 \mathrm{p}<0.01)$.

The recovery of $S$. senanensis was very few in all the plots the study period

243 (data not shown). Among the main competitive species, Rubus idaeus L. subsp.

244 melanolasius Focke and Cirsium kamtschaticum Ledeb. ex DC. germinated mostly by

245 seeds (100 and 95\%, respectively). The effects of the treatment were different by the

246 locations between the two species (Fig. 4ab, p<0.05). In the upper slope, seedlings of

247 R.idaeus subsp. melanolasius were significantly more abundant in the replacing,

248 followed by the screening (Fig. 4a, p<0.01). In contrast, in the lower slope, they were

249 significantly more abundant in the screening, following by the replacing (Fig. 4a,

$250 \mathrm{p}<0.01)$. With regard to the slope location, they were more abundant in the upper slope

251 in the replacing and the standard scarification (Fig. $4 a, p<0.05$ ). On the other hand, in

252 the upper slope, seedlings of $C$. kamtschaticum were significantly more abundant in the 
standard scarification (Fig. 4b, p<0.05). In the lower slope, they were significantly more

254 abundant in the screening (Fig. 4b, p<0.05).

256 Zucc.) Maxim. subsp. giganteus (G.Nicholson) Kitam. and Aralia cordata Thunb.

257 germinated mainly from rhizomes (96, 76 and 29\%, respectively). Again, the effects of

258 the treatment were different by the slope locations for these species (Fig. 4cde, $p<0.05$ ).

259 In the upper slope, juveniles of $F$. sachalinensis were significantly more abundant in the

260 screening and the standard scarification, and they were relatively less in the replacing

261 (Fig. 4c, p<0.05). In this slope, juveniles of $P$. japonicas subsp. giganteus were

262 significantly more abundant in the two treatments leaving surface soil (Fig. 4d, p<0.05),

263 and the appearance of $A$. cordata showed a similar trend (but not statistically

264 significant) among the treatments (Fig. 4e). In the lower slope, all of these species

265 showed the tendency that juveniles were more abundant in the replacing; differences

266 were significant in $F$. sachalinensis and $A$. cordata (Fig. 4ce, $\mathrm{p}<0.001$ ), and juveniles

267 appeared only in the replacing in P. japonicas subsp. giganteus (Fig. 4d). With regard to

268 the slope location, juveniles of $F$. sachalinensis were significantly more abundant in the

269 lower slope in the replacing (Fig. 4c, p<0.001), while they were significantly more

270 abundant in the upper slope in the screening and the standard scarification (Fig. 4c,

$271 \mathrm{p}<0.01)$. Juveniles of $A$. cordata were significantly more abundant in upper slope in the

272 screening (Fig. 4e, p<0.01). 


\section{Discussion}

\section{$274 \quad$ Effects of treatments on soil properties}

275 The three treatments that were examined in this study each exhibited specific soil

276 properties, with a large difference even being observed between the replacing and

277 screening, despite both leaving the surface soil in place.

278 Soils that were treated with the replacing had the highest water contents from the

279 surface to the deep layer in the lower slope (Fig. 2), possibly due to this treatment

280 producing a soil condition that water could easily infiltrate. Generally, the soil water

281 content closely relates to porosity rate of the soil (represented partly by soil hardness)

282 because large numbers of macro-pores increase the water infiltration ability (Beven and

283 Germann 1982; McNabb et al. 2001). Consequently, the existence of coarse rhizomes in 284 the soil with the replacing (Fig. 1c) may have caused macro-pores to occur (Beven and

285 Germann 1982), increasing the porosity rate of the soil. This possibility is supported by

286 the finding that the surface soil temperature, which is generally negatively correlated to

287 soil porosity, was significantly lower with the replacing (Fig. 1d; Matsumoto and

288 Okubo 1977). The undulating surface layer being created by the higher plant debris

289 density with this treatment (Fig. 2a) also seem to contribute to maintain its relatively

290 high soil water condition. In addition, we think that the formation of a crust layer as a

291 result of soil surface compaction combined with the disappearance of vegetation and the

292 litter layer (Norton 1987; Onda and Yukawa 1995) may be related to this result, as this

293 would block the penetration of water into the soil and is expected to be enhanced with

294 the screening compared with the replacing.

295 There were no significant differences in soil water content between treatments in

296 the upper slope (Fig. 2abd), suggesting that the effects of these treatments on soil

297 properties depend on the topographic condition. It is likely that a high water permeation 
ability will promote desiccation in the upper slope when the water supply is less

299 abundant (Siegel-Issem et al. 2005), resulting in the more compacted soil that resulted

300 from the screening having an increased water holding capacity owing to excessive

301 penetration (Gomez et al. 2002; Page-Dumroese et al. 2006). In support of this, it was

302 noted that there was only a small difference in the soil water content between the upper

303 and lower slope locations with the screening (Fig. 2acd). Like the screening, the

304 standard scarification also produced compacted soil, which explains the low soil water

305 content that occurred with this treatment.

\section{Effects on regenerated vegetation}

307 Both the replacing and screening greatly increased the residual pseudo-buried seed

308 density (Fig. 3a). However, the effects varied between these treatments, with more than

309 half of the pseudo-buried seeds (55.2\%) being maintained with the screening and $36.4 \%$

310 remaining with the replacing. This is likely due to the replacing involving plowing the

311 surface soil and plant debris, resulting in many of the pseudo-buried seeds being moved

312 to deeper layers.

313 The main tree species in the study area, $P$. amurense, exhibited the greatest

314 seedling density with the screening, followed in turn by the replacing and the standard

315 scarification (Fig. 3c). P. amurense produces a seed bank and these results clearly

316 reflect the observed pattern for the residual pseudo-buried seed density (Fig. 3a). On the

317 other hand, the two Betula species that were examined in this study had extremely low

318 regenerating seedling densities with the standard scarification, despite previous reports

319 of the emergence of abundant seedlings in the first year after this treatment (Umeki

320 2003), indicating a low level of seed production in the previous year. The seedlings of

321 these Betula species were considered to have originated from buried seeds even though

322 their life span is limited to one to several years (Osumi and Sakurai 1997). 
323 Consequently, our finding that there was no difference in seedling density between the

324 screening and replacing (Fig. 3b) despite the differences in their residual pseudo-buried seed density suggests that the germination and survival rates were higher with the

326 replacing than with the screening. This tendency is consistent with the findings of a

327 previous study considering the appearance of $B$. maximowicziana seedlings from buried 328 seeds (Yamazaki and Yoshida 2018). We think that this is caused by the increased soil

329 water content, which also closely related to the soil hardness and plant-debris density, in 330 the replacing (Fig. 1bc, 2). The microenvironment of the surface soil greatly affects the

331 germination and survival of Betula seedlings in the initial stages (Osumi and Sakurai 332 2002) and desiccation will have a particularly strong negative effect in scarified area, 333 where compacted soil is exposed to direct solar radiation. Therefore, it seems that the 334 replacing, which can maintain a higher soil water content, together with lower soil 335 hardness and higher plant-debris density, provides more safe sites for Betula seedlings.

336 In addition, the lower soil surface temperature in summer in the replacing (Fig. 1d), may 337 have reduced the amount of stress experienced by the seedlings (Davidson et al. 1998).

338 Furthermore, the treatments also affected the germination of competitive species, 339 which may become competitive depending on the site conditions. For $R$. ideaeus subsp. 340 nipponicus, the number of seedlings that germinated was higher on the upper slope than 341 on the lower slope and was lower with the standard scarification (Fig. 4a), reflecting the 342 preference of this species for dry sites and its production of buried seeds (Prévost et al. 343 2010). By contrast, the highest abundance of C. kamtschaticum Ledeb. ex DC. seedlings 344 appeared on the upper slope with the standard scarification treatment (Fig. 4b), 345 indicating its similar preference for dry sites but suggesting that most seedlings 346 originated from seeds that had not been buried. 
cordata mostly reproduce asexually from crushed rhizomes (Tsuyuzaki 1987, 1989), so

349 we initially expected that there would be a higher density of these species with the

350 replacing due to the larger amount of plant debris in the soil (Fig. 1c), most of which

351 contained rhizomes of the plants $(48 \%-78 \%$ of the weight; Yamazaki, unpublished

352 data). However, our results did not necessarily support this prediction, particularly in

353 the upper slope locations (Fig. 4cde). Moreover, there was a tendency for the juvenile

354 densities of these three species to be significantly higher on the lower slope with the

355 replacing, while their emergence on the lower slope was extremely limited with the

356 standard scarification and screening (Fig. 4cde), which was unexpected given their

357 preference for relatively wet conditions (Tatewaki 1971; Umezawa 2007). The reason

358 for this is unclear but we think that the scarifying depth of the treatment could be a

359 causal factor; because the scarifying depth was at the same level between the slope

360 locations in the present study, we suppose that most rhizomes were removed from the

361 lower slope, while part of them were remained in the upper slope where the vertical

362 roots were deeper (the formation of vertical roots is often promoted in many forb

363 species growing in dry locations to allow them to use the water in the deeper layers;

364 Weaver 1958; Nippert and Knapp 2007; Skinner and Comas 2010).

\section{Implications for management}

366 In this study, we clarified the effects of three different scarification treatments on soil

367 conditions, which are expected to help us to predict the regeneration potential of target

368 tree species more precisely. We found that there is no clear advantage of selecting the

369 standard scarification treatment over the other two treatments, as it results in a lower

370 density of pseudo-buried seeds (Fig. 3a) and growth of tree seedlings (Yamazaki and 
371 Yoshida 2018), and importantly, does not necessarily bring about a greater reduction in

372 the reproduction of tall forb species (Fig. 4).

373 The remarkable increase in growth of Betula seedlings by a treatment leaving

374 the surface soil in place (Aoyama et al. 2009) would strongly support the trend of

375 modern forestry aiming economic efficiency (Cossalter and Pye-Smith 2003). However,

376 we clearly demonstrated that the replacing and the screening were totally different and

377 had each advantages and disadvantages. Therefore we conclude that these two

378 treatments should be used properly according to the site conditions and target tree

379 species.

380 Since desiccation of the surface soil is the major limiting factor for seedling

381 establishment (Madsen 1995; Resco de Dios et al. 2005; Yoshida et al. 2005), the high

382 soil water content that was obtained with the replacing as a result of the complex

383 surface soil structure is a distinct advantage. Therefore, we think that the replacing will

384 be most suitable for tree species with higher water demands, such as Betula species.

385 However, it was also apparent that the replacing had one potential risk; it could cause an

386 increase in competitive vegetation, particularly for species that germinate from

387 rhizomes. Therefore, use of the replacing should be avoided at sites where many tall

388 forb species grow alongside dwarf bamboos prior to treatment, particularly when these

389 occur on the lower slopes. While dwarf bamboos can generally be removed successfully

390 by scarification, regeneration failure can occur after the treatment as a result of the rapid

391 growth of competitive species in many cases. For example, it has been reported that $F$.

392 sachalinensis, $P$. japonicas subsp. giganteus, and $A$. cordata, all of which were found in

393 our study plots, often occur at low densities in dwarf bamboo grassland and sometimes

394 form small patches under relatively wet soil conditions (Haruki et al. 1992). Most of

395 these perennial tall forb species germinate from rhizomes, and their vigorous growth 
potential is very likely to shade target tree species in the initial stages of regeneration

397 (Yamazaki, unpublished data).

398 We clearly demonstrated that the screening maintains approximately 1.5 times

399 the amount of pseudo-buried seeds in the soil than the replacing, indicating that it would

400 be the most effective treatment for tree species that produce long-lived seeds such as $P$.

401 amurense. Moreover, a distinct advantage of this treatment over the replacing is its

402 greater ability to reduce the emergence of tall forb species that germinated from

403 rhizomes on lower slopes. Therefore, screening is considered a more suitable option in

404 dwarf bamboo grassland that is relatively wet and in which tall forb species occur.

405 There remains a need to further improve these treatments in the future. At first,

406 it is required to monitor seedlings and competitive vegetation for a longer-term, because

407 the current study only dealt with the first growing-season. Also, we have to pay

408 attention to a possibility that the results may be specific to the site condition; further

409 investigations are necessary in sites with different soil type and properties. In addition,

410 the results of this study suggest that the scarification depth, that has rarely been

411 considered in the past, needs to be changed depending on the location of the site. For

412 instance, for a site that is on an upper slope where there is a possibility that the root

413 systems of former vegetation are deeper, it would be better to apply more intense (i.e.,

414 deeper) scarification. Therefore, in this context, it is necessary to investigate the site-

415 dependent distribution of root systems of major competitive plant species, and to

416 determine the scarification depth that is most efficient for their removal.

\section{Acknowledgements}

418 We would like to thank to two anonymous reviewers for their helpful comments and

419 suggestions. We would sincerely thank N. Suzuki and technical staff of the Uryu

420 Experimental Forest, for their assistance in the field work, and members of the Nayoro 
421 laboratory for their valuable discussion for this study. We also thank A. Okuda for his

422 help to conduct soil analyses.

\section{$423 \quad$ Funding detail}

424 This study was supported by $<$ the research project fund from the Ministry of Education,

425 Culture, Sports, Science and Technology of Japan> under Grant < number 26450187>.

\section{References}

427 Aoyama K, Yoshida T, Kamitani T. 2009. An alternative of soil scarification treatment for forest restoration: effects of soil replacement. Journal of Forest Research 14: $58-62$

430 Ares A, Terry TA, Miller RE, Anderson HW, Flaming BL. 2005. Ground-based forest harvesting effects on soil physical properties and Douglas-fir growth. Soil Science Society of America Journal 69: 1822-1832

Benayas JMR, Bullock JM. 2012. Restoration of biodiversity and ecosystem services on agricultural land. Ecosystems 15: 883-899

Benvenuti S, Macchia M, Miele S. 2001. Quantitative analysis of emergence of seedlings from buried weed seeds with increasing soil depth. Weed Science 49: $528-535$.

438 Beven K, Germann P. 1982. Macropores and water flow in soils. Water Resources Research 18: 1311-1325

440 Butchart SH, Walpole M, Collen B, Van Strien A, Scharlemann JP, Almond RE, et al. 2010. Global biodiversity: indicators of recent declines. Science 328: 1164-1168

442 Cossalter C, Pye-Smith C. 2003. Fast-wood forestry: myths and realities (Vol. 1). 
444 Davidson EA, Belk E, Boone RD. 1998. Soil water content and temperature as independent or confounded factors controlling soil respiration in a temperate mixed hardwood forest. Global Change Biology 4: 217-227

Finkeldey R, Ziehe M. 2004. Genetic implications of silvicultural regimes. Forest Ecology and Management 197: 231-244

Fløistad IS, Hylen G, Hanssen KH, Granhus A. 2018. Germination and seedling establishment of Norway spruce (Picea abies) after clear-cutting is affected by timing of soil scarification. New Forests 49: 231-247

Gomez A, Powers RF, Singer MJ, Horwath WR. 2002. Soil compaction effects on growth of young ponderosa pine following litter removal in California's Sierra Nevada. Soil Science Society of America Journal 66: 1334-1343

González-Rodríguez V, Navarro-Cerrillo RM, Villar R. 2011. Artificial regeneration with Quercus ilex L. and Quercus suber L. by direct seeding and planting in southern Spain. Annals of Forest Science 68: 637-646

Goto S, Tsuda S. 2007. Scarification for promoting sustainable resource management of Betula maximowicziana in a second-growth forest. [in Japanese with English summary] Journal of the Japanese Forest Society 86:138-143

Haruki M, Itagaki T, Namikawa K. 1992. Forest construction in the Doran river watershed, Nakagawa experimental forest, Hokkaido University. [in Japanese]

Ito E, Hashimoto T, Aizawa S, Ishibashi S. 2018. Contemporary significance of soil scarification for promoting tree regeneration in Hokkaido, northern Japan. [in Japanese with English summary] Japanese Journal of Forest Environment 60: 71- 
Kohm KA, Franklin JF. (Eds.). 1997. Creating a forestry for the 21st century: The science of ecosytem management. Island Press

Löf M, Dey DC, Navarro RM, Jacobs DF. 2012. Mechanical site preparation for forest restoration. New Forests 43: 825-848

Madsen P. 1995. Effects of soil water content, fertilization, light, weed competition and seedbed type on natural regeneration of beech (Fagus sylvatica). Forest Ecology and Management 72: 251-264

Matsumoto J, Okubo T. 1977. Experimental study on heat transfer characteristics of soils. [in Japanese] Proceedings of the Japan Society of Civil Engineers 257: 5360

McNabb DH, Startsev AD, Nguyen H. 2001. Soil wetness and traffic level effects on bulk density and air-filled porosity of compacted boreal forest soils. Soil Science Society of America Journal 65: 1238-1247

Messier C, Puettmann KJ, Coates KD. 2013. Managing forests as complex adaptive systems: building resilience to the challenge of global change. Routledge, Oxford

Narukawa Y, Yamamoto S. 2002. Effects of dwarf bamboo (Sasa sp.) and forest floor microsites on conifer seedling recruitment in a subalpine forest, Japan. Forest Ecology and Management 163: 61-70

487 Noguchi M, Yoshida T. 2004. Tree regeneration in partially cut conifer-hardwood mixed forests in northern Japan: roles of establishment substrate and dwarf bamboo. Forest Ecology and Management 190: 335-344

490 Norton LD. 1987. Micromorphological study of surface seals developed under 491 simulated rainfall. Geoderma 40: 127-140

492 Nyland RD. 2016. Silviculture: concepts and applications. Waveland Press 
Nippert JB, Knapp AK. 2007. Linking water uptake with rooting patterns in grassland $494 \quad$ species. Oecologia 153: 261-272

495 Onda Y, Yugawa N. 1995. The influences of understories on infiltration rates in Chamaecyparis obtusa plantations (II) laboratory experiments. [in Japanese with English summary] Journal of the Japanese Forestry Society 77: 399-407

Osumi K, Sakurai S. 1997. Seedling emergence of Betula maximowicziana following human disturbance and the role of buried viable seeds. Forest Ecology and Management 93: 235-243

501 Osumi K, Sakurai S. 2002. The unstable fate of seedlings of the small-seeded pioneer tree species, Betula maximowicziana. Forest ecology and Management 160: 85-95

Page-Dumroese DS, Jurgensen MF, Tiarks AE, Ponder Jr F, Sanchez FG, Fleming RL et al. 2006. Soil physical property changes at the North American Long-Term Soil Productivity study sites: 1 and 5 years after compaction. Canadian Journal of Forest Research 36: 551-564

Prévost M, Raymond P, Lussier JM. 2010. Regeneration dynamics after patch cutting and scarification in yellow birch-conifer stands. Canadian Journal of Forest Research 40: 357-369

R Development Core Team. (2019). R: A language and environment for statistical computing. R Foundation for Statistical Computing, Vienna; [accessed 2019 May 20]. http://www.R-project.org/

513 Resco de Dios VR, Yoshida T, Iga Y. 2005. Effects of topsoil removal by soil514 scarification on regeneration dynamics of mixed forests in Hokkaido, Northern Japan. Forest Ecology and Management 215: 138-148 
516 Reyes J, Thiers O, Gerding V. 2014. Characterization of soil properties of Nothofagus spp. forest with and without scarification in the Andean region of southern Chile. Journal of Soil Science and Plant Nutrition 14: 101-113

Sato H. 1998. Regeneration or many tree species by soil scarification under canopies (I) - Mechanisms from seed dispersal to seedling establishment - . [in Japanese] Bulletin of the Hokkaido Forestry Research Institute 35: 21-30

Schütz JP. 1999. Close-to-nature silviculture: is this concept compatible with species diversity?. Forestry $72: 359-366$

Shono K, Cadaweng EA, Durst PB. 2007. Application of assisted natural regeneration to restore degraded tropical forestlands. Restoration Ecology 15: 620-626

Siegel-Issem CM, Burger JA, Powers RF, Ponder F, Patterson SC. 2005. Seedling root growth as a function of soil density and water content. Soil Science Society of America Journal 69: 215-226

Siry JP, Cubbage FW, Ahmed MR. 2005. Sustainable forest management: global trends and opportunities. Forest Policy and Economics 7: 551-561

Skinner RH, Comas LH. 2010. Root distribution of temperate forage species subjected to water and nitrogen stress. Crop Science 50: 2178-2185

Tatewaki M. 1971. Forest vegetation in the Teshio and Nakagawa District Experiment forests of Hokkaido University, Prov. Teshio, N. Hokkaido, Japan. [in Japanese

537 Thompson I, Mackey B, McNulty S, Mosseler A. 2009. Forest resilience, biodiversity, with English summary] Research Bulletins of the College Experiment Forests and climate change. In Secretariat of the Convention on Biological Diversity, Montreal. Technical Series 43: 1-67 
540 Tsuyuzaki S. 1987. Origin of plants recovering on the volcano Usu, northern Japan,

$541 \quad$ since the eruptions of 1977 and 1978. Vegetatio 73: 53-58

542 Tsuyuzaki S. 1989. Analysis of revegetation dynamics on the volcano Usu, northern

543 Japan, deforested by 1977-1978 eruptions. American Journal of Botany 76: 1468-

$544 \quad 1477$

545 Umeki K. 2003. The Regeneration of Natural Forests on Hokkaido, Northern Japan. [in

546 Japanese with English summary] Journal of the Japanese Forestry Society 85:

$547 \quad 246-251$

548 Umezawa S. 2007. Wild Flower of Hokkaido. [in Japanese] Hokkaido University Press

549 Walle IV, Van Camp N, Van de Casteele L, Verheyen K, Lemeur R. 2007. Short-

550 rotation forestry of birch, maple, poplar and willow in Flanders (Belgium) I-

551 Biomass production after 4 years of tree growth. Biomass and Bioenergy 31: 267-

$552 \quad 275$

553 Weaver JE. 1958. Classification of root systems of forbs of grassland and a

$554 \quad$ consideration of their significance. Ecology 39: 393-401

555 Yamazaki H, Yoshida T. 2018. Significance and limitation of scarification treatments

556 on early establishment of Betula maximowicziana, a tree species producing buried

557 seeds: effects of surface soil retention. Journal of Forest Research 23: 166-172

558 Yildiz O, Eşen D, Sarginci M. 2009. Long-term site productivity effects of different

559 Rhododendron control methods in eastern beech (Fagus orientalis Lipsky)

560 ecosystems in the Western Black Sea region of Turkey. Soil use and Management

$561 \quad 25: 28-33$

562 Yonekura K, Kajita T. 2003. YList. [accessed 2019 September 15]. http://ylist.info 
563 Yoshida T, Iga Y, Ozawa M, Noguchi M, Shibata H. 2005. Factors influencing early

564 vegetation establishment following soil scarification in a mixed forest in northern

565 Japan. Canadian Journal of Forest Research 35: 175-188

566 Zaczek JJ. 2002. Composition, diversity, and height of tree regeneration, 3 years after

567 soil scarification in a mixed-oak shelterwood. Forest Ecology and Management

$568 \quad 163: 205-215$

569 
570 Figure 1 . The average and standard deviation $(n=8)$ of soil properties. Different letters 571 indicate significant difference among the treatments (n.s.; not significant). For all the 572 variables, because the effect of location was not significant (see Appendix-table 1) the 573 data obtained from upper- and lower- slope were pooled and shown. For the soil 574 hardness (b) and plant-debris density (c), only the result of the most surface layer was 575 shown; the statistical differences among the treatment were same in the other depths.

576 Figure 2. The average and standard deviationfor each upper- and lower location $(\mathrm{n}=4)$

577 of soil water content in the four depths. Different letters indicate significant difference 578 among the treatments (n.s.; not significant). The difference between the slope-locations 579 is shown as text in each panel.

580 Figure 3. The average and standard deviation of residual pseudo-buried seed density $581(n=4)$ and emergences of tree seedlings $(n=8)$. Different letters indicate significant 582 difference among the treatments. For all the variables, because the effect of location was 583 not significant (see Appendix-table 2) the data obtained from upper- and lower- slope 584 were pooled and shown.

585 Figure 4. The average and standard deviation for each upper- and lower location $(n=4)$ 586 of emergences of seedlings or juveniles of competitive species. Bars indicate standard 587 deviation. Different letters indicate significant difference among the treatments (n.s.; not 588 significant). The difference between the slope-locations is shown as text in each panel.

589 Appendix-table 1. The results of the generalized liner mixed model (GLMM) explaining 590 the soil properties. The explanatory variables were "Treatment", "Location" and their 591 interaction-. The study areas (canopy openings) were considered as a random factor.

592 The coefficients and p-values (in parentheses) are shown. "NS" indicates the variable 593 not selected in the final model.

594 Appendix-table 2. The results of the generalized liner mixed model explaining variables 595 relate to vegetation recovery. The explanatory variables were "Treatment", "Location" 596 and their interaction. The study areas (canopy openings) were considered as a random 597 factor. The coefficients and p-values (in parentheses) are shown. "NS" indicates the 598 variable not selected in the final model. 
Various scarification treatments produce the different regeneration potentials for trees and forbs through changing soil properties

Appendix

Appendix Table The results of the generalized liner mixed model (GLMM) explaining the soil properties.

The explanatory variables were "Treatment", "Location" and their interaction-. The study areas (canopy openings) were considered as a random factor The coefficients and p-values (in parentheses) are shown. "NS" indicates the variable not selected in the final model.

\begin{tabular}{|c|c|c|c|c|c|c|c|c|c|c|c|c|c|}
\hline \multirow{2}{*}{\multicolumn{2}{|c|}{ Soil properties }} & \multirow[b]{2}{*}{$\mathrm{n}$} & & \multirow[b]{2}{*}{ Intercept } & \multicolumn{2}{|c|}{ Treatment } & \multirow{2}{*}{$\begin{array}{c}\begin{array}{c}\text { Location } \\
\text { Lower } \\
\text { (Low) }\end{array} \\
\text { now }\end{array}$} & \multicolumn{2}{|c|}{ Interaction } & \multirow[b]{2}{*}{ AIC } & \multicolumn{3}{|c|}{ Random effect } \\
\hline & & & & & $\begin{array}{c}\text { Replacing } \\
\text { (Rep) }\end{array}$ & $\begin{array}{c}\text { Screening } \\
\text { (Scr) }\end{array}$ & & Rep : Low Scr & : Low & & & Study area & Residual \\
\hline \multirow{2}{*}{\multicolumn{2}{|c|}{$\begin{array}{l}\text { Soil surface micro-topography } \\
\text { variance }\end{array}$}} & \multirow[t]{2}{*}{8} & \multirow{2}{*}{$\begin{array}{l}\text { Estimate } \\
\text { p-value }\end{array}$} & 1.67 & 7.58 & 0.01 & $\mathrm{NS}$ & $\mathrm{NS}$ & $\mathrm{NS}$ & \multirow{2}{*}{111.28} & \multirow{2}{*}{$\begin{array}{l}\text { Variance } \\
\text { Std.Dev. }\end{array}$} & 0.00 & 0.16 \\
\hline & & & & 0.37 & 0.01 & 1.00 & NS & NS & NS & & & 0.00 & 4.03 \\
\hline \multirow{6}{*}{ Soil hardness } & \multirow{2}{*}{$0-5 \mathrm{~cm}$} & \multirow{2}{*}{8} & Estimate & 17.33 & -8.03 & -1.82 & NS & NS & NS & \multirow{2}{*}{86.74} & Variance & 0.00 & 4.16 \\
\hline & & & $\mathrm{p}$-value & 0.00 & 0.00 & 0.18 & NS & NS & NS & & Std.Dev. & 0.00 & 2.04 \\
\hline & \multirow{2}{*}{$5-10 \mathrm{~cm}$} & \multirow{2}{*}{8} & Estimate & 18.57 & -8.08 & -1.13 & NS & NS & NS & \multirow{2}{*}{81.46} & Variance & 0.00 & 3.10 \\
\hline & & & $\mathrm{p}$-value & 0.00 & 0.00 & 0.33 & NS & NS & NS & & Std.Dev. & 0.00 & 1.76 \\
\hline & \multirow{2}{*}{$10-20 \mathrm{~cm}$} & \multirow{2}{*}{8} & Estimate & 19.72 & -6.82 & -0.90 & NS & NS & NS & \multirow{2}{*}{84.56} & Variance & 0.00 & 3.69 \\
\hline & & & p-value & 0.00 & 0.00 & 0.47 & NS & NS & NS & & Std.Dev. & 0.00 & 1.92 \\
\hline \multirow{6}{*}{$\begin{array}{l}\text { Plant-debris } \\
\text { density }\end{array}$} & \multirow{2}{*}{$0-2.5 \mathrm{~cm}$} & \multirow{2}{*}{8} & Estimate & 5.90 & 34.00 & 8.16 & NS & NS & NS & \multirow{2}{*}{161.96} & Variance & 29.46 & 248.30 \\
\hline & & & $\mathrm{p}$-value & 0.47 & 0.00 & 0.43 & NS & NS & $\mathrm{NS}$ & & Std.Dev. & 5.43 & 15.76 \\
\hline & \multirow{2}{*}{$2.5-5 \mathrm{~cm}$} & \multirow{2}{*}{8} & Estimate & 3.48 & 15.92 & 6.19 & NS & NS & NS & 12650 & Variance & 3.22 & 35.41 \\
\hline & & & $\mathrm{p}$-value & 0.25 & 0.00 & 0.12 & NS & NS & NS & 126.59 & Std.Dev. & 1.79 & 5.95 \\
\hline & $5-10 \mathrm{~cm}$ & 8 & Estimate & 1.00 & 21.91 & 6.57 & NS & NS & NS & 131.84 & Variance & 0.00 & 50.95 \\
\hline & $5-10 \mathrm{~cm}$ & 8 & p-value & 0.76 & 0.00 & 0.17 & NS & NS & NS & 131.84 & Std.Dev. & 0.00 & 7.14 \\
\hline Soil tempera & ture & 8 & Estimate & 29.50 & -2.56 & 0.97 & NS & NS & NS & 87.21 & Variance & 0.00 & 4.27 \\
\hline & ture & & $\mathrm{p}$-value & 0.00 & 0.07 & 0.47 & NS & NS & NS & 81.21 & Std.Dev. & 0.00 & 2.07 \\
\hline & $0-25 \mathrm{~cm}$ & 8 & Estimate & 19.88 & 1.34 & 4.98 & 3.83 & 4.08 & $\begin{array}{l}-1.82 \\
\end{array}$ & 32 & Variance & 3.53 & 16.80 \\
\hline & $0-2.5 \mathrm{~cm}$ & 8 & $\mathrm{p}$-value & 0.00 & 0.75 & 0.25 & 0.37 & 0.50 & 0.76 & 32 & Std.Dev. & 1.88 & 4.10 \\
\hline & $25-5 \mathrm{~cm}$ & 8 & Estimate & 31.30 & 5.10 & -1.05 & 1.75 & 0.37 & 6.94 & 11922 & Variance & 0.00 & 15.94 \\
\hline Soil w & $2.5-5 \mathrm{~cm}$ & 8 & $\mathrm{p}$-value & 0.00 & 0.23 & 0.80 & 0.67 & 0.95 & 0.25 & 119.22 & Std.Dev. & 0.00 & 3.99 \\
\hline Soll water col & $5-10 \mathrm{~cm}$ & 8 & Estimate & 29.73 & 10.54 & 7.36 & 0.67 & 3.04 & 1.01 & & Variance & 0.65 & 3.55 \\
\hline & $5-10 \mathrm{~cm}$ & 8 & p-value & 0.00 & 0.00 & 0.00 & 0.73 & 0.28 & 0.71 & 92.13 & Std.Dev. & 0.81 & 1.89 \\
\hline & & 8 & Estimate & 29.31 & -1.24 & 8.94 & -0.44 & 12.18 & -6.81 & & Variance & 0.00 & 16.35 \\
\hline & 10 & 8 & p-value & 0.00 & 0.77 & 0.05 & 0.91 & 0.06 & 0.26 & $11 / .38$ & Std.Dev. & 0.00 & 4.04 \\
\hline
\end{tabular}

Appendix Table The results of the generalized liner mixed model explaining variables relate to vegetation recovery.

The explanatory variables were "Treatment", "Location" and their interaction. The study areas (canopy openings) were considered as a random factor. The coefficients and p-values (in parentheses) are shown. "NS" indicates the variable not selected in the final model.

\begin{tabular}{|c|c|c|c|c|c|c|c|c|c|c|c|c|}
\hline \multirow[b]{2}{*}{ Soil properties } & \multirow[b]{2}{*}{$\mathrm{n}$} & & \multirow[b]{2}{*}{ Intercept } & \multicolumn{2}{|c|}{ Treatment } & \multirow{2}{*}{$\begin{array}{c}\text { Location } \\
\text { Lower } \\
\text { (Low) }\end{array}$} & \multicolumn{2}{|c|}{ Interaction } & \multirow[b]{2}{*}{ AIC } & \multicolumn{3}{|c|}{ Random effect } \\
\hline & & & & $\begin{array}{l}\text { Replacing } \\
\text { (Rep) }\end{array}$ & $\begin{array}{l}\text { Screening } \\
\text { (Scr) }\end{array}$ & & Rep : Low & $\overline{\text { Scr : Low }}$ & & & Study area & Residual \\
\hline \multirow{2}{*}{$\begin{array}{c}\text { Residual } \\
\text { pseud-burid seed density } \\
\end{array}$} & \multirow{2}{*}{4} & \multirow{2}{*}{$\begin{array}{l}\text { Estimate } \\
\text { p-value }\end{array}$} & -3.02 & 2.01 & 2.42 & NS & $\overline{\mathrm{NS}}$ & NS & \multirow{2}{*}{618.43} & Variance & NS & \\
\hline & & & 0.00 & 0.00 & 0.00 & $\mathrm{NS}$ & $\mathrm{NS}$ & $\overline{\mathrm{NS}}$ & & Std.Dev. & $\mathrm{NS}$ & $\mathrm{NS}$ \\
\hline \multirow{2}{*}{ Betula spp. } & \multirow{2}{*}{8} & \multirow{2}{*}{$\begin{array}{l}\text { Estimate } \\
\text { p-value }\end{array}$} & 0.16 & 0.51 & 0.52 & $\mathrm{NS}$ & NS & $\mathrm{NS}$ & \multirow{2}{*}{21.59} & Variance & 0.00 & 0.11 \\
\hline & & & 0.31 & 0.03 & 0.03 & $\mathrm{NS}$ & NS & $\mathrm{NS}$ & & Std.Dev. & 0.00 & 0.33 \\
\hline \multirow{2}{*}{ Phellodendron amurense } & \multirow{2}{*}{8} & Estimate & 0.22 & 0.25 & 0.63 & NS & NS & NS & \multirow{2}{*}{21.47} & Variance & 0.05 & 0.09 \\
\hline & & $\mathrm{p}$-value & 0.28 & 0.20 & 0.00 & NS & NS & $\overline{\mathrm{NS}}$ & & Std.Dev. & 0.23 & 0.29 \\
\hline \multirow{2}{*}{$\begin{array}{c}\text { Rubus idaeus } \\
\text { subsp. nipponicus }\end{array}$} & \multirow{2}{*}{8} & Estimate & 2.33 & 3.23 & 1.98 & -1.15 & -1.83 & 0.40 & \multirow{2}{*}{88.15} & Variance & 0.45 & 2.89 \\
\hline & & $\mathrm{p}$-value & 0.10 & 0.09 & 0.27 & 0.52 & 0.46 & 0.87 & & Std.Dev. & 0.67 & 1.70 \\
\hline \multirow{2}{*}{$\begin{array}{l}\text { Cirsium kamtschaticm } \\
\text { var. kamtschaticum }\end{array}$} & \multirow{2}{*}{8} & Estimate & 0.98 & -0.88 & -0.85 & -0.96 & 0.98 & 1.10 & \multirow{2}{*}{47.29} & Variance & 0.00 & 0.33 \\
\hline & & $\mathrm{p}$-value & 0.04 & 0.16 & 0.16 & 0.13 & 0.26 & 0.21 & & Std.Dev. & 0.00 & 0.58 \\
\hline \multirow{2}{*}{ Fallopia sachalinensis } & \multirow{2}{*}{8} & Estimate & 2.29 & -0.75 & -0.56 & -2.27 & 4.79 & 0.81 & \multirow{2}{*}{99.51} & Variance & 4.74 & 4.32 \\
\hline & & p-value & 0.31 & 0.73 & 0.79 & 0.30 & 0.13 & 0.79 & & Std.Dev. & 2.18 & 2.08 \\
\hline \multirow{2}{*}{$\begin{array}{l}\text { Petasites japonicus } \\
\text { subsp. giganteus }\end{array}$} & \multirow{2}{*}{8} & Estimate & 0.10 & 0.48 & 0.38 & -0.10 & 0.00 & -0.38 & \multirow{2}{*}{36.46} & Variance & 0.12 & 0.13 \\
\hline & & $\mathrm{p}$-value & 0.77 & 0.22 & 0.33 & 0.78 & 1.00 & 0.49 & & Std.Dev. & 0.34 & 0.37 \\
\hline \multirow{2}{*}{ Aralia cordata } & \multirow{2}{*}{8} & Estimate & 0.13 & 0.06 & 0.08 & -0.08 & 0.17 & -0.08 & \multirow{2}{*}{10.21} & Variance & 0.02 & 0.03 \\
\hline & & p-value & 0.46 & 0.74 & 0.65 & 0.65 & 0.53 & 0.75 & & Std.Dev. & 0.14 & 0.18 \\
\hline
\end{tabular}


Figure 1

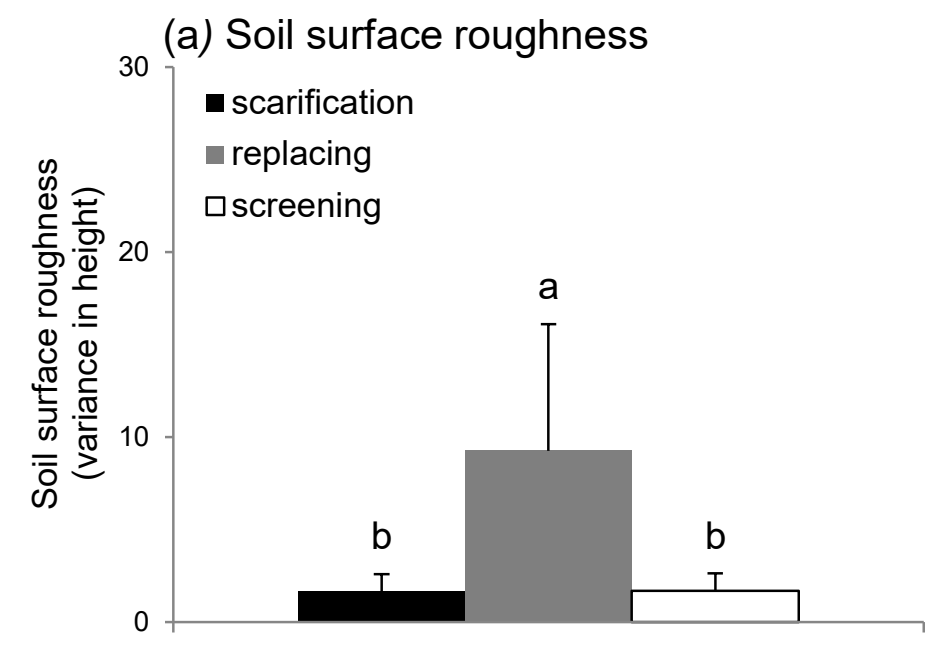

(c) Plant-debris density

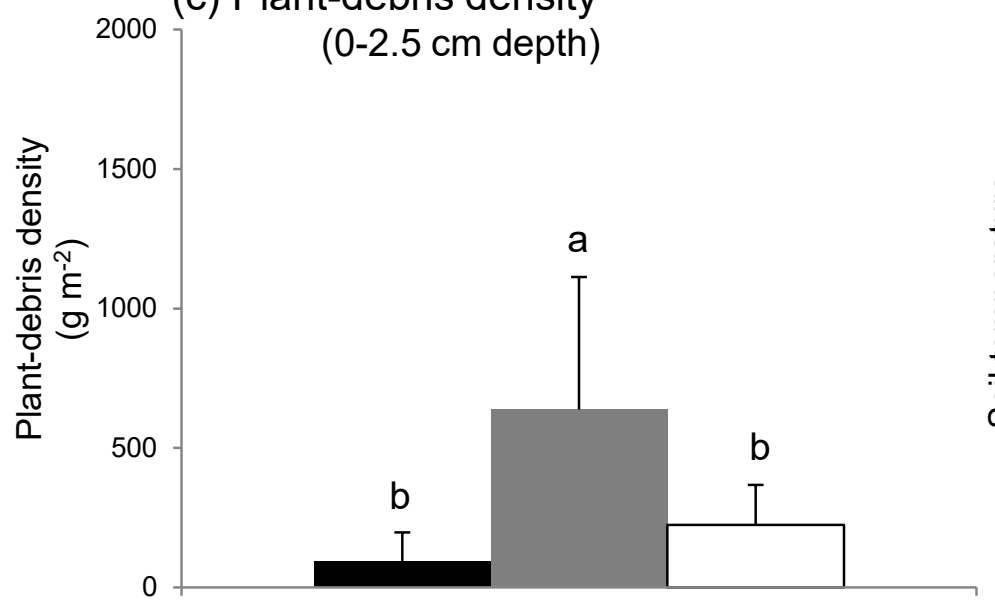

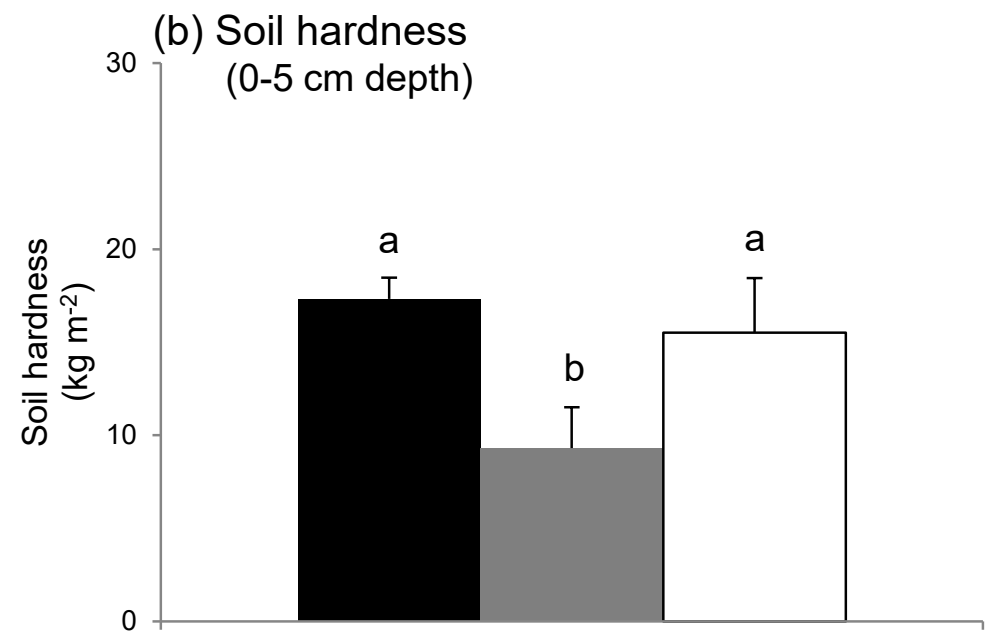

(d) Soil surface temperature

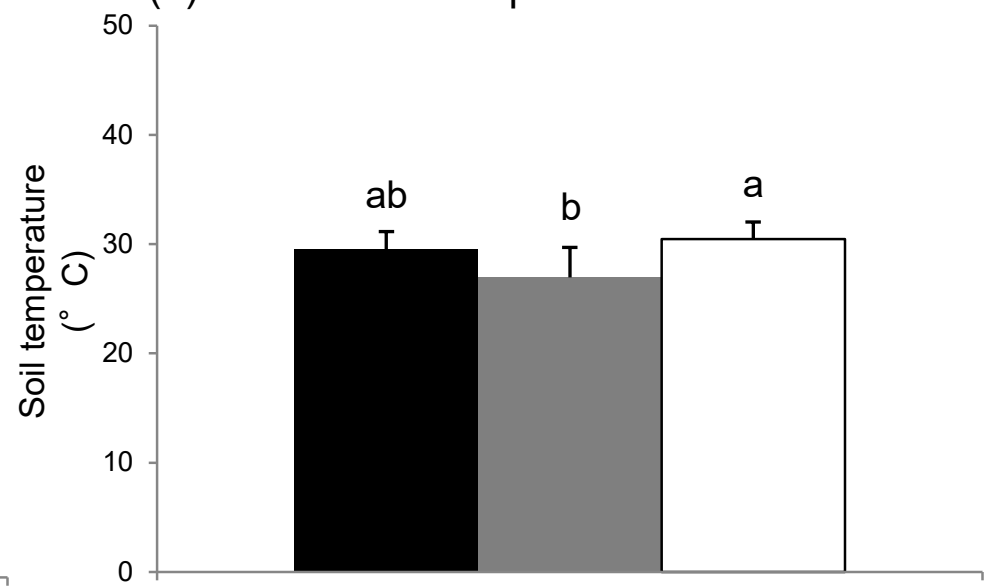


Figure 2
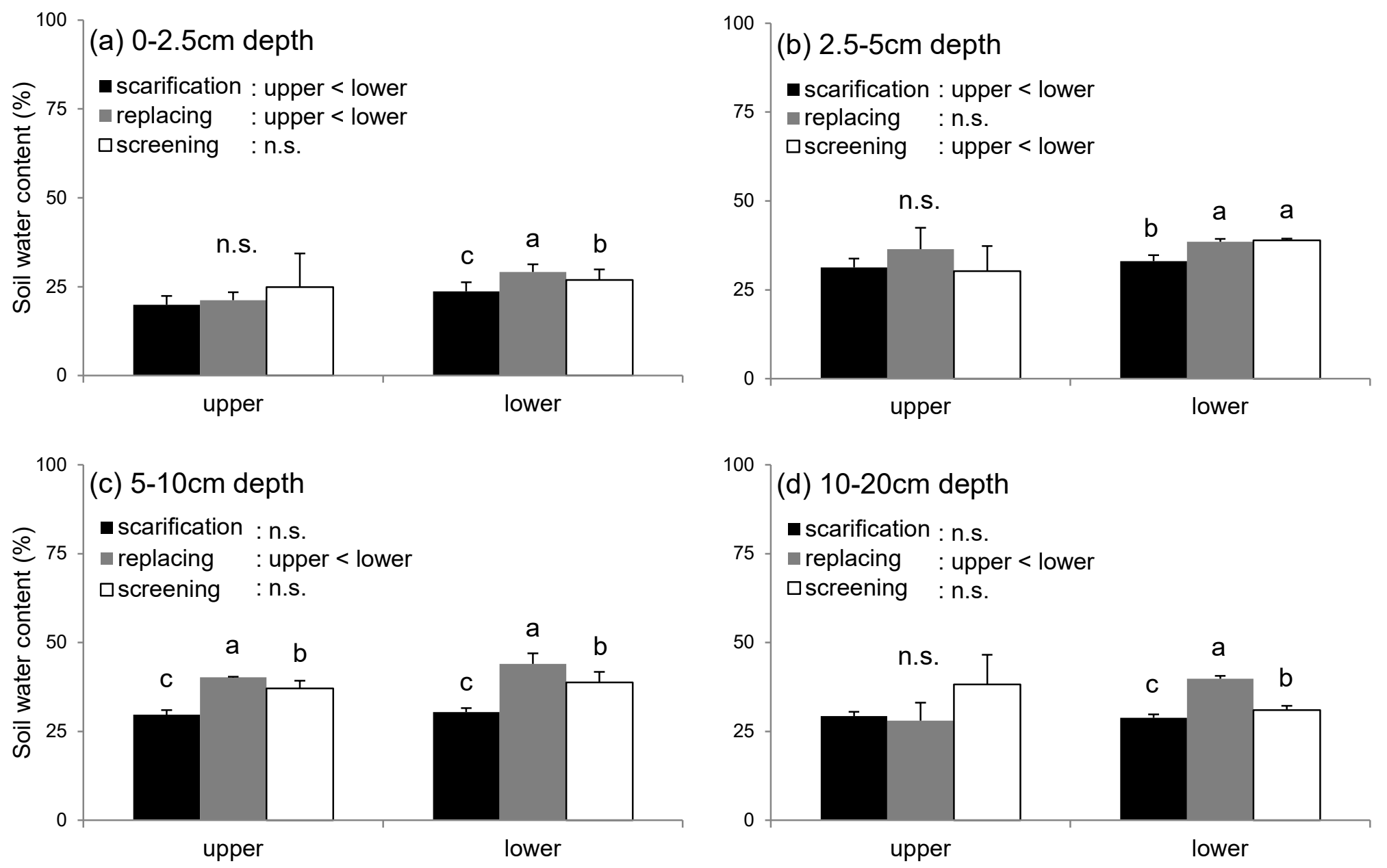
Figure 3

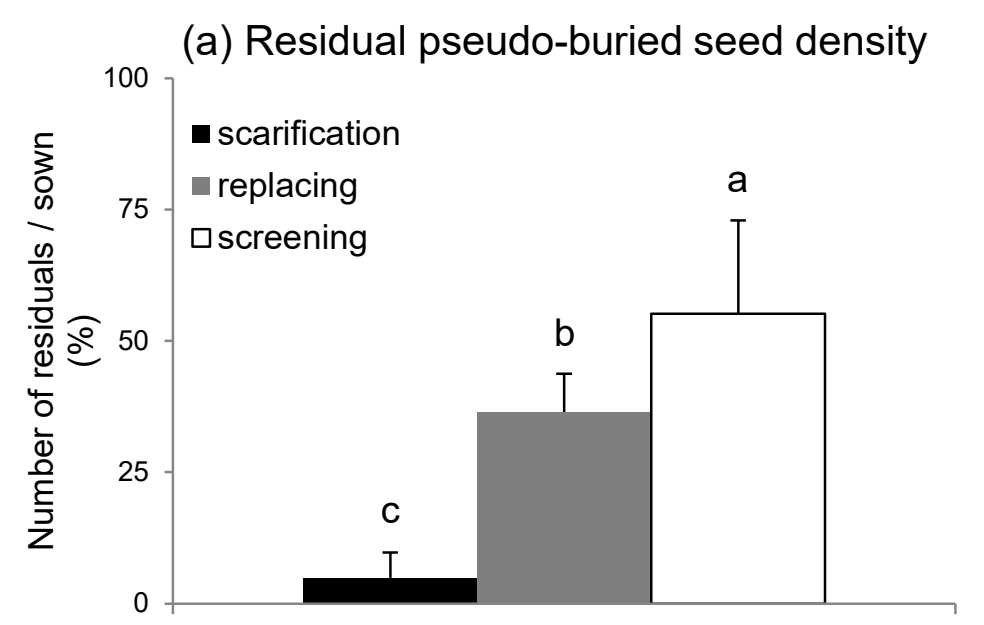

(b) Betula spp.

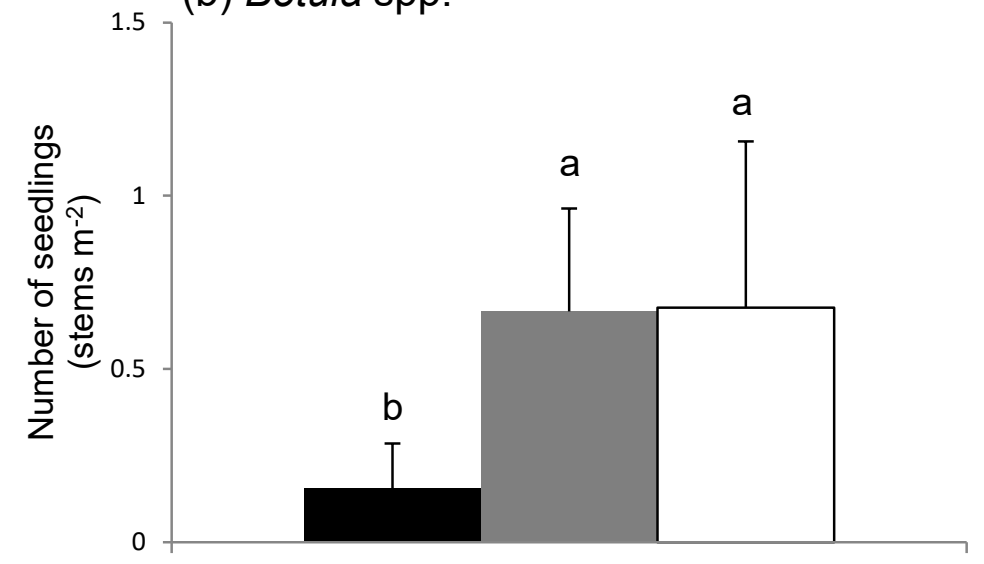

(c) Phellodendron amurense

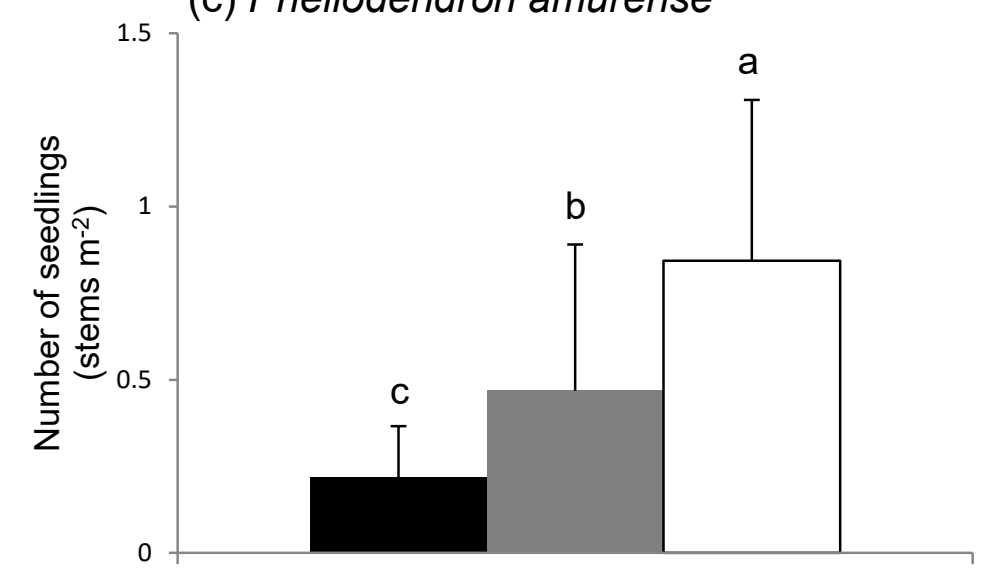




\section{Figure 4}
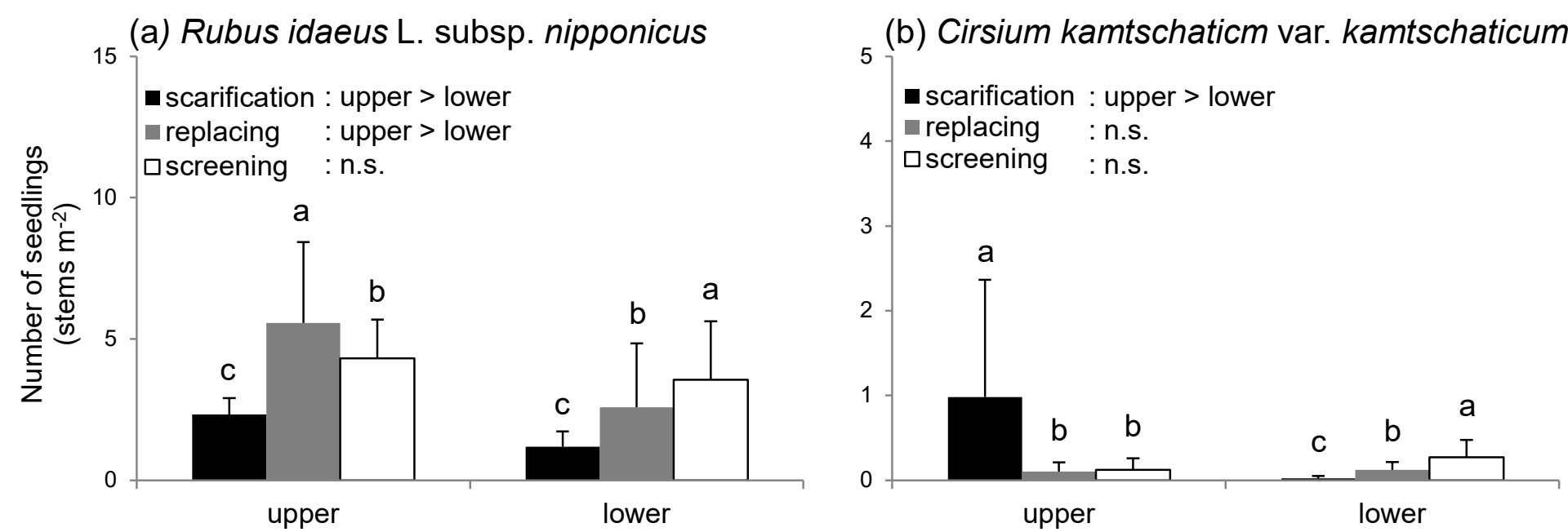

(c) Fallopia sachalinensis

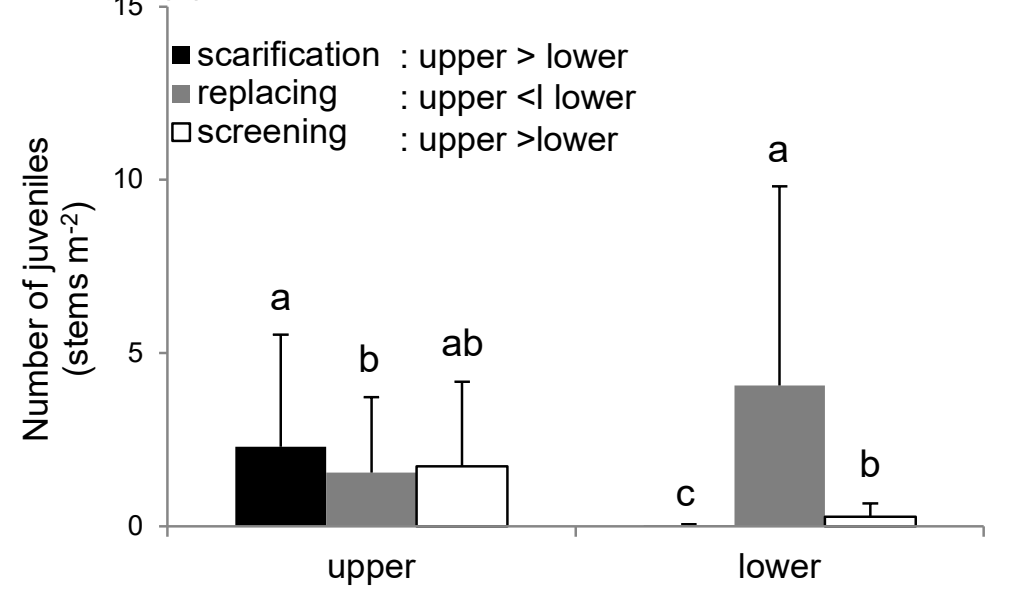

(d) Petasites japonicus subsp. giganteus

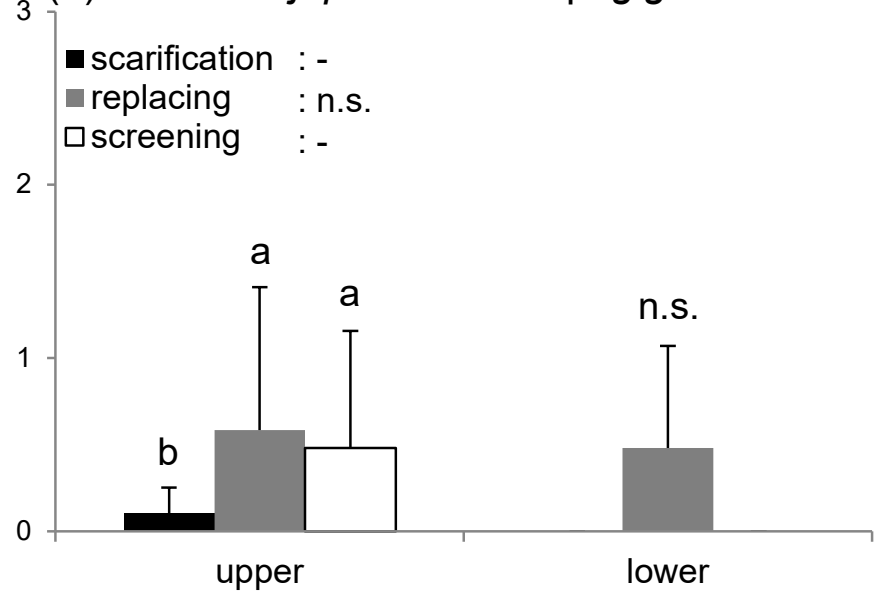

(e) Aralia cordata

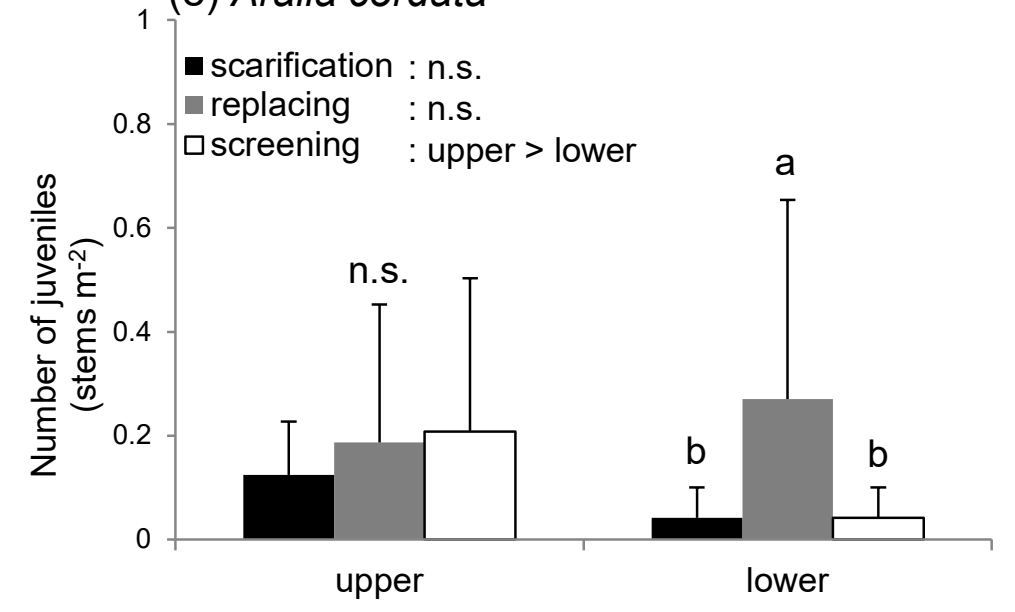

